UDC: 332.122

JEL Classification: C 15

doi: 10.31767/nasoa.1-2.2019.02

T. H. TAMRAZOV,

PhD (Biology), Assistant Professor, Department of scientific and statistical research, Research and Statistical Innovation Center, Department of Plant Physiology and Biotechnology, Research Institute of Crop Husbandry, Baku

\title{
Improving Food Supply throught Increasing Local Production in Azerbaijan
}

Research reviews and accumulated experiences show that irrespective of the branch of agriculture, its main production means are soil. The output of agricultural products and the development of different types of farms depend on the use of soil and its fertility. Azerbaijan has large areas of fertile lands that can produce high yields of agricultural plants. The purpose of the research is to investigate the sources and factors of food security that are of particular importance for ensuring food security of Azerbaijan and meeting the needs of the population in foodstuffs. The current state of food production in Azerbaijan, ways to improve food supply, and food market problems are investigated. Statistical data on the output of cereal grain products, legumes, potato, vegetables and melons, fruit and berries over 2003-2017 are given. The self-sufficiency and import dependence of Azerbaijan in plant products are estimated. The statistical analysis shows that Azerbaijan is still unable to meet the demand for basic food products through their domestic production; the share of imports of grain, grain legumes, vegetable oils, milk and dairy products in the total consumption remains to be high. This means that the positions of foreign producers in the domestic agricultural and food markets have been strengthening compared with the local producers' positions in respective product segments. Another problem is related with the economic efficiency in the agricultural sector, including more efficient use of land, material and technical means, dissemination of agricultural innovations, intensification of production processes. Recommendations on optimization of food supply and achievement of food safety in Azerbaijan are given.

Keywords: food supply, production, food security, imports, exports, self-sufficiency.

\section{T. ТАМРАЗОВ,}

кандидат біологічних наук, дочент, відділ науково-статистичних досліджень, Інновачійний иентр досліджень і статистики, відділ фізіології рослин і біотехнологій, Науково-дослідниизкий інститут рослинництва, Баку

\section{Підвищення рівня продовольчої безпеки Азербайджану через збільшення місцевого виробництва}

Метою дослідження є аналіз чинників, які відіграють особливо важливу роль у забезпеченні продовольчої безпеки Азербайджану $і$ задоволенні потреб населення у продуктах харчування. Розглянуто поточні умови виробниитва продовольчої продукиї в Азербайджані, шляхи покращення забезпечення продовольством, проблеми ринку продовольчої продукиії. Надано статистичні дані про виробництво основних видів продукиії рослинництва протягом 2003-2017 років. Розраховано показники самозабезпечення Азербайджану продукиією рослинниитва та його залежності від іï імпорту. Статистичний аналіз показав, що Азербайджан не може задовольнити попит на основні продукти харчування шляхом їх внутрішнього виробництва. Надано рекомендації щодо оптимізачії забезпечення продуктами харчування і досягнення продовольчої безпеки в Азербайджані.

T. H. Tamrazov, 2019 
Ключові слова: продовольство, виробництво, продовольча безпека, імпорт, експорт, самодостатність.

\section{T. TAMPA3OB, кандидат биологических наук, доиент, отдел научно-статистических исследований, Инновачионный центр исследований и статистики, отдел физиологии растений и биотехнологий, Научно-исследовательский институт растениеводства, Баку \\ Повышение уровня продовольственной безопасности Азербайджана за счет увеличения местного производства}

Целью исследования является анализ факторов, играющих особо важную роль в обеспечении продовольственной безопасности Азербайджана и удовлетворении потребностей населения в продуктах питания. Рассмотрены текущие условия производства продовольственной продукции в Азербайджане, пути улучшения обеспечения продовольствием, проблемь рынка продовольственной продукции. Представлены статистические данные о производстве основных видов продукции растениеводства в течение 2003-2017 годов. Рассчитаны показатели самообеспечения Азербайджана продукцией растениеводства и его зависимости от ее импорта. Статистический анализ показал, что Азербайджан не может удовлетворить спрос на основные продукты питания путем их внутреннего производства. Представлены рекомендации по оптимизации обеспечения продуктами питания и достижению продовольственной безопасности в Азербайджане.

Ключевые слова: продовольственное обеспечение, производство, продовольственная безопасность, импорт, экспорт, самообеспечение.

In recent years, the rapid growth dynamics of Azerbaijan have become more prominent in the success of the agrarian sector. Food security is one of the important directions of realization of the state economic development concept, as well as the intensive development of agricultural production and provides unrestricted foodstuffs. Being one of the important components of the state's economic security, it also reflects the economic and political power of the state in the context of globalization. Four key factors have special importance in ensuring food security. These factors include the availability of production capacities, the implementation of the production, the quality of products and the purchasing power of the population. Establishment of state reserve funds at the expense of domestic production has special economic importance in ensuring food security in the country. Therefore, the main goal is to create a reserve fund for the creation and use of a reserve fund, which plays an important role in the increase of local production $[1 ; 2]$.

Studies show that one of the major problems in raising domestic production is to protect the economic interests of the state and protect the domestic market from external influences to ensure food security. Increasing the production of agricultural products and promoting entrepreneurial activity and raising revenue in bringing it to the required level are closely linked with increasing the production of local products [3].The main factors affecting food security and the economic interests and political sovereignty of the state are the problems that arise in the food supply of the population of the country. Thus, improving food security is one of the key indicators of population's living standards [2;3].

From this point of view, successful implementation of the state's agrarian policy, increasing agricultural production and improving its quality indicators are largely dependent on market conditions. Expansion of entrepreneurship activity in meeting the population's demand for food products and provision of agricultural producers with material and technical resources meeting modern requirements. It should be noted that it is crucial to find the solution of resource provision in the study of the specialization of the regions, including the composition, characteristics, productivity and areas of the regions. In addition, the efficient use of labor resources, including the labor force, in the supply of food security resources is also considered to be one of the important factors $[3 ; 8]$. 


\section{СТАТИСТИКА}

Studies show that the most important factor in providing food security at the expense of domestic production is intensification of production $[1 ; 12]$.

The State Program on Reliable Provision of Population with Food Products in the Republic of Azerbaijan for 2008-2015 states that reliable food supply is a key requirement for economic stability and social sustainability of each country [2]. One of the key factors influencing the formation of a reliable food supply in the country is the creation of sufficient food reserves in the country, as well as achieving competitive production. From this point of view, it is of particular importance to identify and implement all possible forms and directions of the formation of state food reserves to ensure adequate food security of the population in market conditions. The economic power of the state is estimated based on the level of development of regions [3; 4]. The improvement of the domestic food market is directly linked to the country's food security and the achievement of a reliable food supply for the country's population. Establishment of agrarian infrastructure to create sustainable livelihoods with agrarian products facilitated the elimination of seasonal crop yields and ultimately increased production efficiency $[8 ; 10]$.

The market mechanism has been proven by many countries in the agrarian sector, according to the growth rate of production in the agrarian sector. In this regard, the research is aimed at investigating existing problems $[9 ; 11]$.

The main purpose of the research is to investigate the sources of food security that are of particular importance in ensuring food security and meeting the needs of the population in foodstuffs, the study of certain aspects of important factors. Based on the findings after the research, it is the preparation of proposals and recommendations for the solution of existing problems. First of all, we have tried to explore the current state of food production in our country and ways of promising development in the field of agrarian food supply, study of food market problems. There are a number of factors that affect food security. One of them is the production process. During the survey, we assessed the level of food supply in the country at the expense of domestic production. Basically, research is planned in the following areas:

- increasing the role of local production in ensuring food security, the organization of competitive domestic production, the need to increase food reserves;

- basic factors affecting food security, self-sufficiency level of basic food products;

- evaluation of the current status of various food products in the country;

- develop practical proposals for the organization of optimal supply and volume of food safety.

The methodological basis of the research is the laws of the Republic of Azerbaijan, normative-legal documents adopted by the government, data from the State Statistical Committee, various monitoring results, state programs, studies and works of agrarian researchers from republican and foreign countries [12].

As we know, the main purpose of the intensification of agriculture was the comprehensive reimbursement of the ever increasing demand of the population by increasing the volume of production and improving its quality. In modern economic conditions, the scheme of the product from producer to consumer is reflected in the agrarian market of the country:

Manufacturer - Supply organizations - Intermediary trading institutions - Consumer

Research has shown that some changes have occurred in the country's agrarian sector with the creation of product sales through different channels. The sale of products through individuals (especially through direct markets and firm stores) has significantly improved in recent years [2; 12].

The poor sales of agricultural products in the agribusiness system to the intermediary commercial organizations in the country under modern economic conditions are mainly due to several reasons:

1) In the current period, grain, meat and dairy products are strategically important for the state and are largely due to the fact that most of these products produced in farms are not used for state needs to provide food security.

2) Costs of the products, which are freely sold by market entities (potato, vegetable, dairy and other products produced by family and peasant farms), rapid depletion, non-sales of high yields, additional processing, high transportation costs, etc. as the case may be. 
A complex system of measures should be developed to strengthen the positions of the economy in domestic and foreign markets. The Complex Measures System is intended to raise competitiveness. Increasing competitiveness involves reducing the cost of a particular product and improving its quality $[7 ; 11]$.

It is impossible to take this field into the industrial bases of agricultural production without adequate capital investments and to meet increasing demand for the population's food products, and the industry's agricultural raw materials $[4 ; 6]$.

Information on the production of agricultural products in food balances includes data from all manufacturers (state agricultural enterprises and organizations, collective farms, open and closed joint stock companies, limited and additional responsible economic societies, agricultural production cooperatives, other agricultural enterprises and organizations, entrepreneurs, household peasant households, and households) [12].

When calculating the "production" indicator for agricultural products (meat, dairy, eggs, cereals and grains, vegetables and fruit), information on the production of plant and animal products for all categories of farms is calculated for the calendar year. Data on cereals and grains are calculated according to the weight of the meat, according to the weight of the meat, based on the basic fat content (dairy production on agricultural producers in physical weight, agricultural producers, dairy products manufactured by the processing enterprises, and milk fat in basic fat content) $[2 ; 12]$.

In Azerbaijan, agricultural producers mainly deal with their products and, in some cases, agricultural products.

Thus, the term "product" is used here in two ways: firstly, the production of agricultural products by agricultural producers; and the second is the production of processing products from processing and recycling of agricultural products in processing enterprises, agricultural producers and households $[2 ; 6]$.

For this, let's take a look at the food balances of Azerbaijan on crop and livestock products. In fact, many products that form the basis of the consumer basket should be created, thereby protecting the food market from artificial price increases.

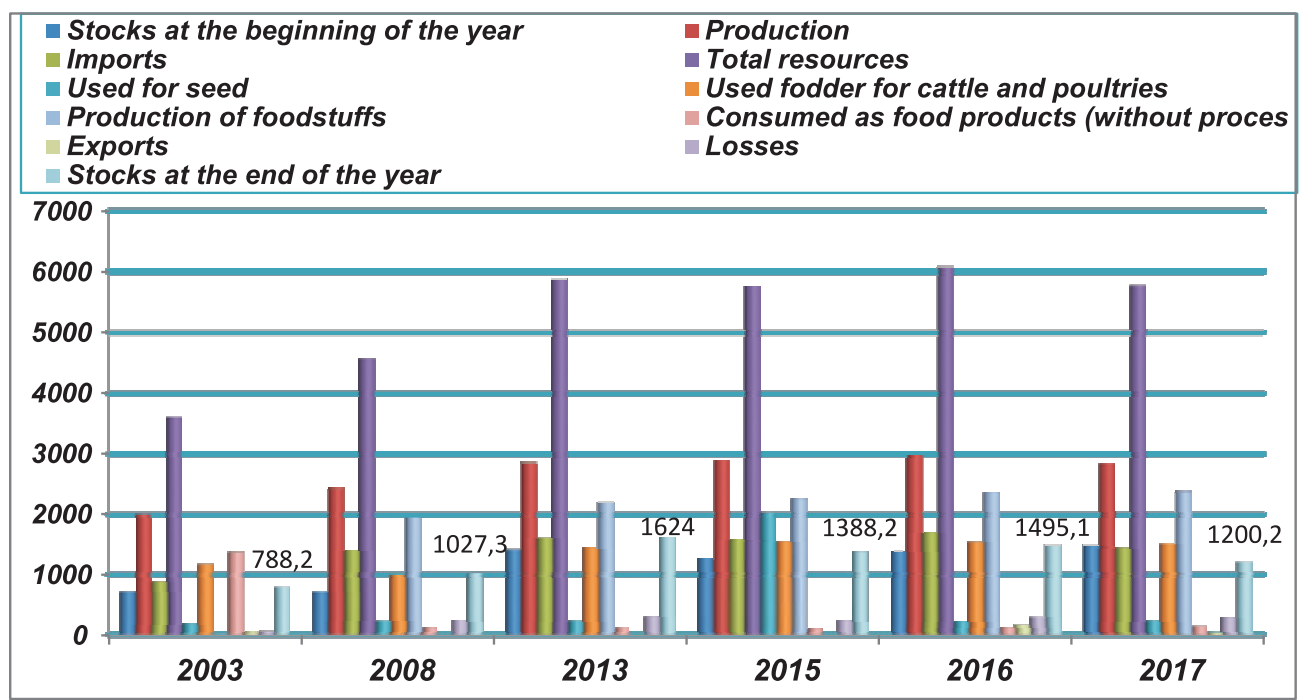

Figure 1. Food balances on cereal grain products, thousand tons

Source: [12]

Varieties of agricultural crops in the Republic of Azerbaijan are reflected in diagrams. Looking at food balances in the Republic of Azerbaijan, we see that cereal grains totaled 876,800 tons in 2003, while in 2013 this figure increased by 734,700 tons to 1611,500 tons. In 2017, it was 1438.1 thousand tons less than in the previous year. At the beginning of 2013, the balance of grain was 1414,300 tons, and the remainder at the end of the year was more than 209,700 tons with 1624 thousand tons. The remainder at the beginning of the year in 2017 was 1495.2 thousand tons, and the remainder at the end of the year was 1200.2 thousand tons. 


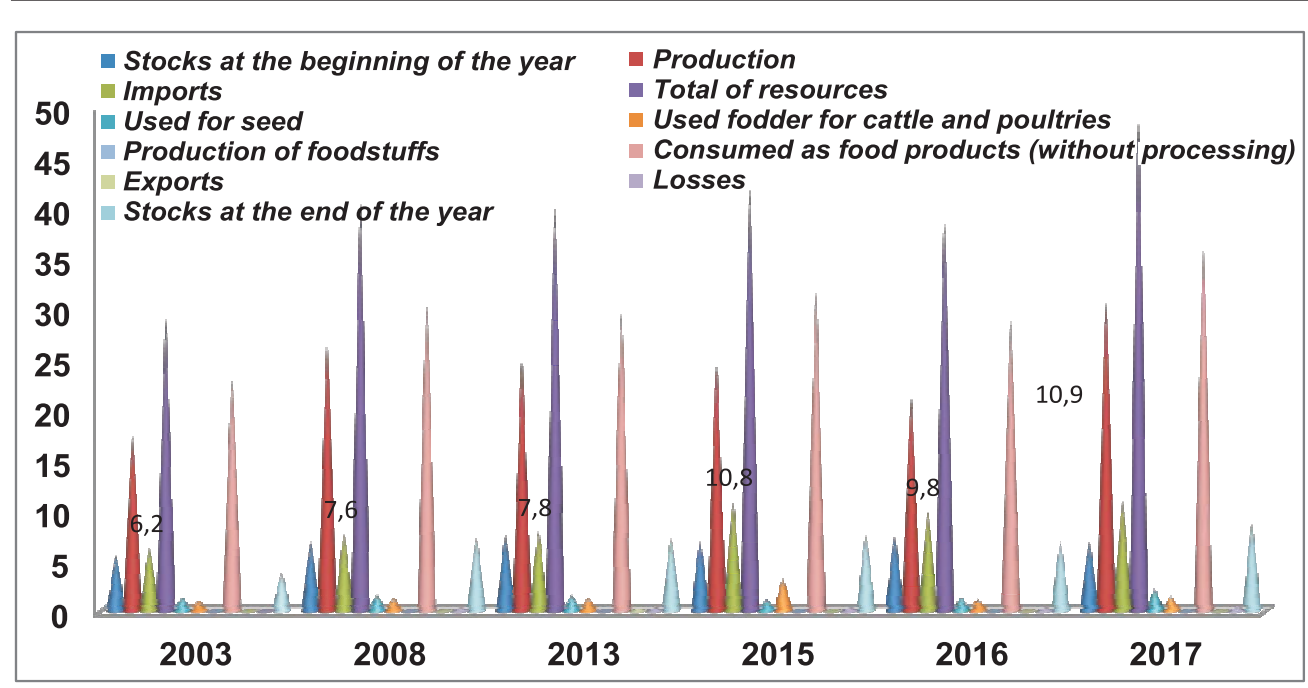

Figure 2. Food balances for legumes, thousand tons

Source: [12]

Unlike grains in cereals, the remainder of the year was 5.5 thousand tons in 2003, 6.8 in 2008, 7.5 thousand tons in 2013, and 6.8 thousand tons in 2017. Production of cereals was 17.4 percent in 2003 and 30.7 thousand tons in 2017 . It is clear from the dynamics that there is a sharp increase in production over the past period.

Compared to imports, it was 6.2 percent in 2003 and 10.9 thousand tons in 2017.Despite the increase in production, there is also an increase in imports. This also gives rise to the fact that the population's demand is not fully met. In this case, it is important to increase the production of agricultural crops in the first place and at the same time comply with the correct agrotechnical requirements.

According to the previous dynamics, key indicators for potato production have variable dynamics for years.

As can be seen from the figure, potato production in 2017 compared to the previous year (592.2-534.3) was more than 57.9 thousand tons, while production (913.9-992.8) was less than 78.9 thousand tons.

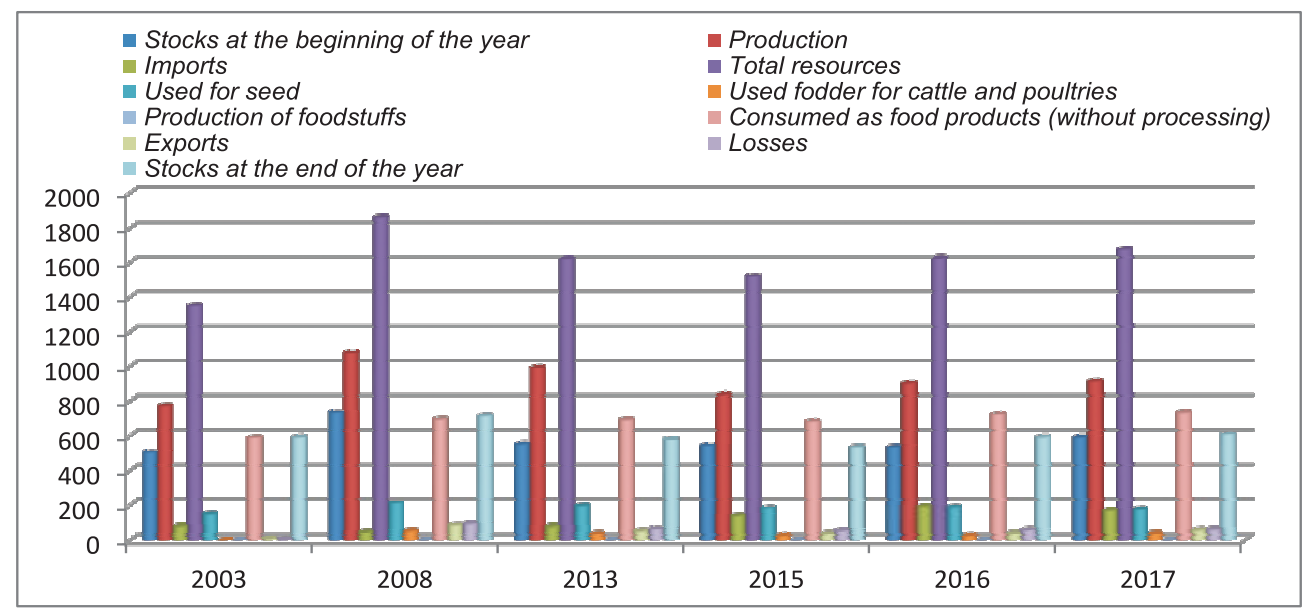

Figure 3. Food balances on potato production, thousand tons

Source: [12]

Vegetables are the main indicator on the garden (179.5-189.2), almost 97,000 tons less, and on the fruit (40.6-46.6) and grain exports in 2003 amounted to 45,000 tons. 
In 2017, exports amounted to 36,000 tons. Potato imports amounted to 78.6 thousand tons in 2003 and 168.8 thousand tons in 2017. Looking at the exports of potatoes, we see that in 2003 it was 12.4 thousand tons, and in 2017 it was 57.7 thousand tons. This means an increase of 24.3 thousand tons compared to 2003.

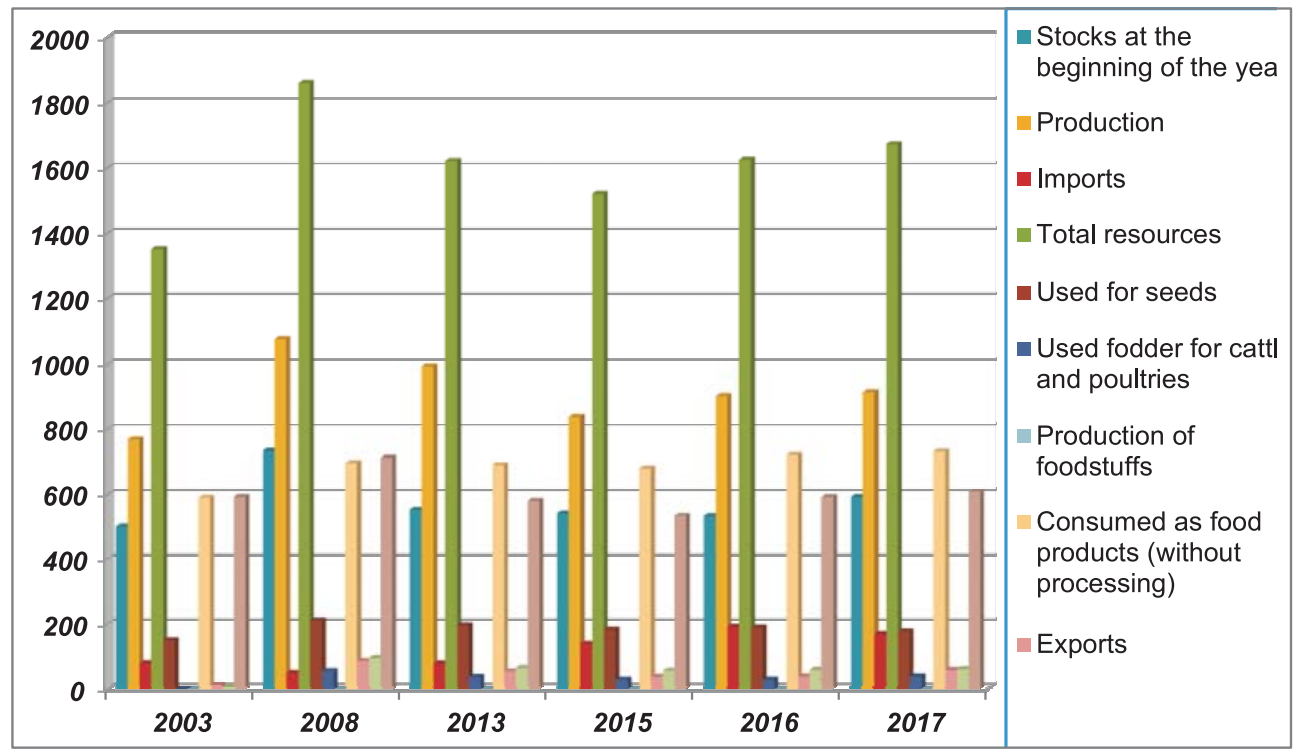

Figure 4. Food balances on vegetables and melons, thousand tons Source: [12]

The imports of vegetables and melons were 29.1 thousand tons in 2003, 26.8 thousand tons in 2008, 37.6 thousand tons in 2013, and finally 168.7 thousand tons in 2017. It is observed that in 2003 it is 139.7 thousand tons less than in 2017. Exports are expected to be 57.7 thousand tons in 2017. In this case, it was 45.3 thousand tons higher than in 2003.

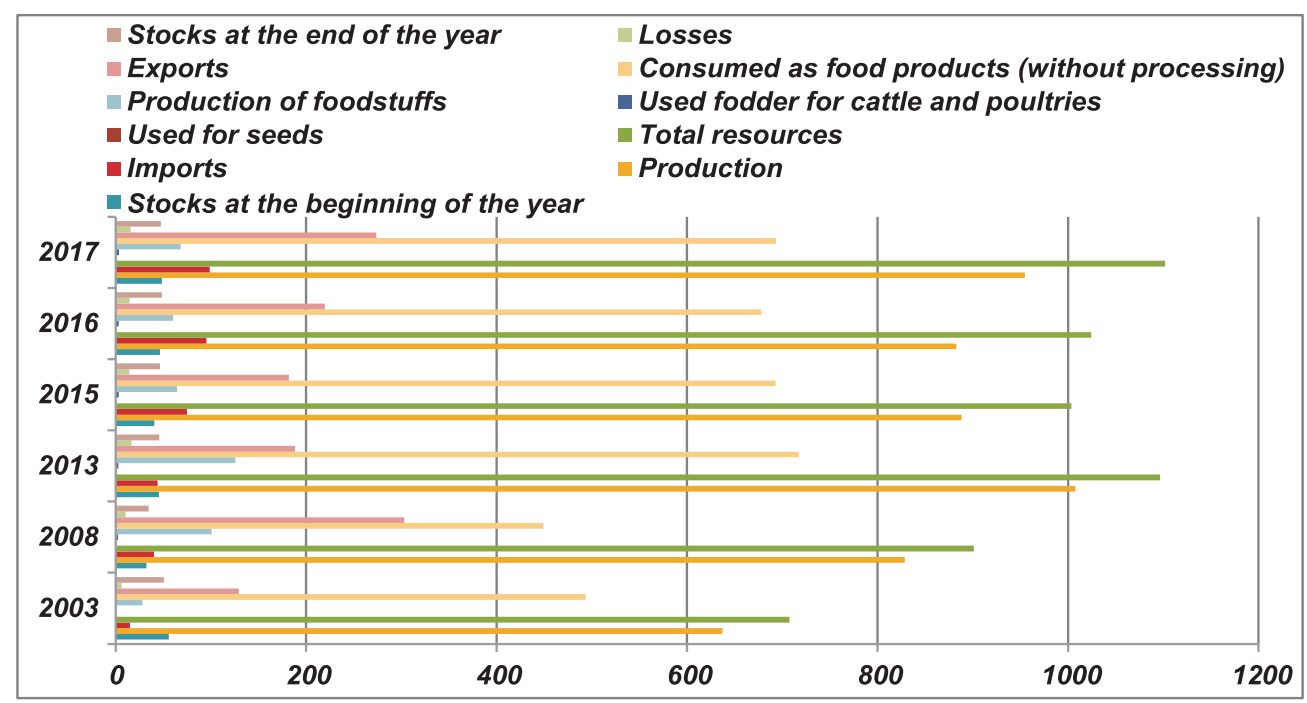

Figure 5. Food balances on fruit and berries, thousand tons

Source: [12]

According to the results of fruit and berry products, imports were 14.8 thousand tons in 2003 and 98.7 thousand tons in 2017. It is worth noting that it is 59.9 thousand tons more than in the previous year. 


\section{СТАТИСТИКА}

As regards Ihraa, 129.2 thousand tons in 2003, 303.1 thousand tons in 2008, 188.3 thousand tons in 2013, 182 thousand tons in 2015 and 273.7 thousand tons in 2017 organized. According to the data, most exports were observed in 2008. Generally, growth is observed in comparison with previous years.

As it is seen from the data, the share of imported products in the structure of product reserves created on the remaining products excluding garden products continued to increase. The grain and grain products segment of Azerbaijan's food market is currently more dependent on international markets. Apparently, over the past five years, approximately $30 \%$ of the created reserves of cereals and grains have been imported. The share of imports of cereals and grain in the country's consumption of plant products is even greater. This is due to the fact that almost all of the grain imported by Azerbaijan is food oriented and goes directly to the consumption of the population.

In recent years, the dynamics of food production in agrarian sector in the regions of Azerbaijan is more noticeable in livestock breeding. Last year, the level of self-sufficiency of livestock products of the country's population increased significantly.

The volume of imports and exports means the amount of products imported and exported from the country as a result of transactions carried out by persons living in the Republic or enterprises operating in the country.

According to international experts, food safety indicators in the Republic of Azerbaijan have improved significantly and have been moderate in comparison with previous years.

It should not be overlooked that it is an integral part of food supply and food security.

The source of foodstuffs created here is also of great importance. In particular, it is necessary to eliminate dependence on foreign countries in food production, and to create the opportunity for the population to meet the food needs at the expense of local production.

By determining the annual consumption volumes, it is possible to determine the ratio between production and imports and its competitiveness. It is impossible to determine the level of food supply of the population with an international standard. All factors, from the geographical position of society to the national mentality, should be taken into consideration.

Let's consider the level of self-regulation in our republic.

Of course, the increase in imports volumes on the back of the annual increase in food production is partly due to the increase in the consumption level of the population. Nevertheless, the reduction of imports volumes and parallel increase in exports should be considered as one of the main tasks facing the country's economy. Self-sufficiency (SS) and foreign trade (imports) levels are the calculated values based on balance sheet data. The methodology recommended by the UN Food and Agriculture Organization (FAO) is used during their calculation.

In order to calculate the level of self-sufficiency, the volume of production is calculated by dividing the output after the total amount of products exported from the total amount of imported products:

$$
\left.C_{\text {Selfuf }}=\text { production / (production + imports - exports }\right) * 100 .
$$

The dynamics of indicators are shown in Figure 6.

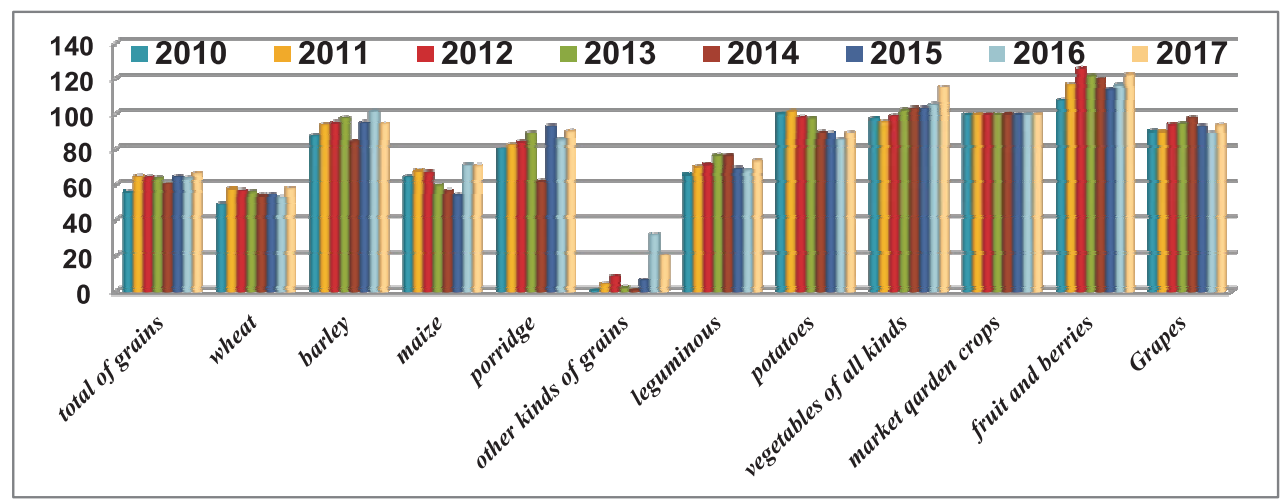

Figure 6. Level of self-sufficiency of plant products, percent Source: [12] 
During the analyzed years some changes were observed in the level of self-sufficiency and dependence on imports of basic crops.

As you can see from the picture, it has been given indicators for each product over the years. The level of cereal crops was $56.5 \%$ in 2010 and $66.3 \%$ in 2017 , which means a $8 \%$ increase. The legumes are $65.8 \%$ in 2010 , and $73.7 \%$ in $2017 . I n$ terms of potato dynamics, it can be noted that in 2010 it was $100.5 \%$, and in 2017 it was $89.2 \%$. It was $11.4 \%$ less than the previous one. The level of self-sufficiency in all types of vegetable products was $97.6 \%$ in 2010 and $115.2 \%$ in 2017. Here, too, there is a slight increase. In fruit and berries it is observed $107.9 \%$ in 2010 and $122.4 \%$ in 2017 . There is also an increase over the previous one. As far as grape production is concerned, there is also an increase in self-improvement.

Thus, in the end it is possible to note that growth of all plant products has been observed.

On the other hand, it is necessary to determine imports dependence. When we look at the imports and exports process in our country, we see that the growth rate of exports volumes is relatively higher than imports. This will allow substantial positive changes in the importsexports balance in the coming years. The level of dependence on foreign trade (imports) is calculated based on the ratio of imports to the absolute amount taken from the total volume of production and imports:

$$
C_{\text {Importlependence }}=\text { Imports } /(\text { production }+ \text { imports }- \text { exports }) * 100
$$

Domestic consumption reflects the products consumed in production needs, the products used for the production of food products, the personal consumption (consumption) of the population, the loss of the products, and all the products used to produce non-food products.

Figure 7 shows the dynamics of imports dependence on each agricultural product by different years. Thus, about $10 \%$ decrease in grains is observed from 2010 to 2017. There is also a decrease in dependence on imports of leguminous plant products. Unlike other products, in potatoes growth is observed: $6.9 \%$ in 2010 and $11.8 \%$ in 2017 . This means $11 \%$ increase. Unlike potatoes, in all types of vegetables, as in other products, there is a decrease. There is also a decrease in fruit and berries. In 2010, it was $22.4 \%$, and in 2017 it dropped to $9.6 \%$.

Comparison of statistical data shows that, while increasing the production of agricultural products in our country reduces the risk of food security, it is still unable to meet the demand for basic food products at the expense of domestic production. As can be seen from the table data, the share of imported commodities on grain and grain legumes in the total consumption by the country's population is at a high level. It has been revealed in the study that vegetable oils, milk and dairy products are quite high.

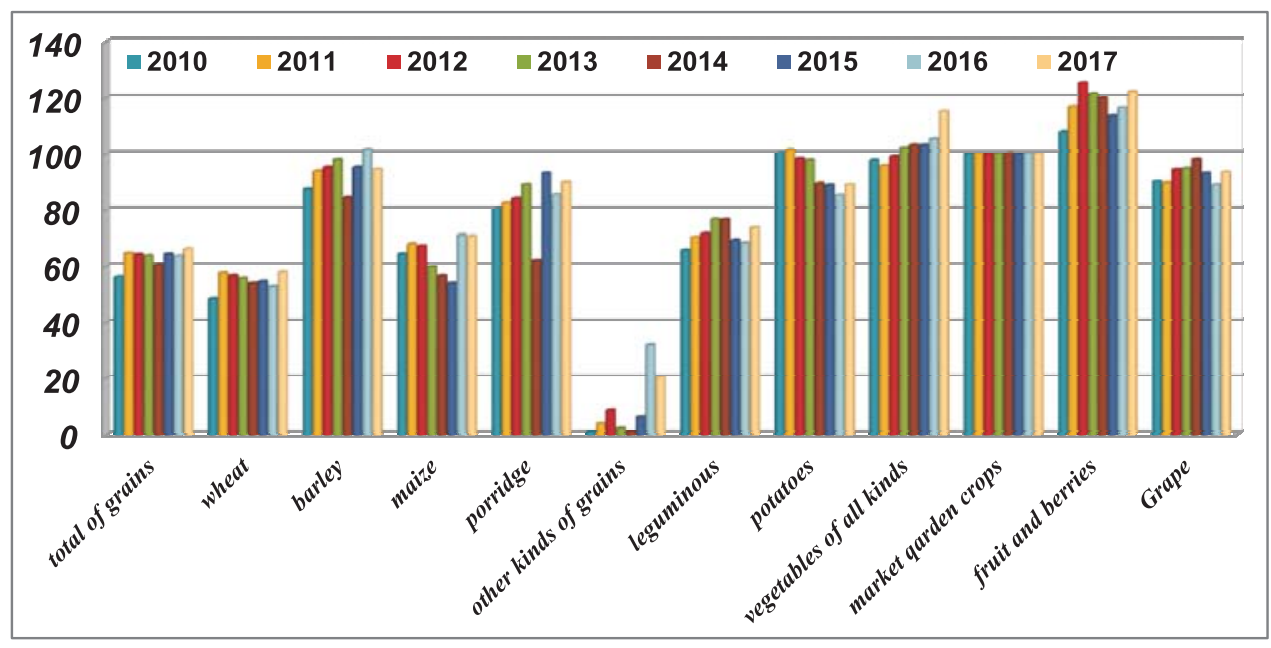

Figure 7. İmport dependence of plant products, percent

Source: [12]

This means that the positions of producers from the foreign countries in the country's agricultural and food products market are strengthening, as compared with the local 


\section{СТАТИСТИКА}

producers' positions on those product segments. Effective measures should be developed and implemented to prevent this from reducing the imports of product segments for preventing this and increasing the level of food security of the country.

In addition to increasing the production of agricultural products in front of the agrarian sector, there are also problems with increasing the economic efficiency of production. This is the production of agricultural products; more efficient use of land, material and technical means, application of scientific and technical progress in production, intensification of production processes, etc. is required.

The analysis shows that potential food security in our republic can be repaid at the expense of domestic production. In this case, full and effective use of land resources is one of the key conditions. It is possible to create a feed base of livestock at the expense of the lands returned to the crop circulation, thus achieving the production of competitive livestock products in the republic. At present, the lack of feed bases leads to a high cost of livestock products, which cannot continue to compete with imported products.

Conclusion. As a result of the conducted research, the following suggestions and conclusions are appropriate for ensuring the population's food security in the country.

- The main factor in ensuring food security in the country is the increase of the role of local production in agrarian sphere, organization of competitive domestic production, increase of food reserves, etc. should be.

- In the near future, the main criterion for the positive changes in the imports-exports balance should be that the growth rates of exports volumes in the country are relatively higher than imports.

- While increasing the production of agricultural food products in our country reduces the risk of food security, it is important to take appropriate measures to meet the demand for basic food products at the expense of domestic production.

- Ensure efficient use of land resources, which is the main source of agricultural production, acceleration of irrigation and melting works, including the involvement of relevant crops in mountainous areas.

- Consumption should be reduced to a minimum to allow local producers to enter production from their production location.

- In general, increasing the economic efficiency of production should be developed the development strategy of the food market and its separate product segments (major types of food products segments).

- In line with the application of modern innovative selection methods, the new approach should be developed in addition to the use of modern methods to analyze selected species of agribio diversity, hybrid, form estimates and results in databases.

- Adhering to innovation technologies during production development can have a positive impact on the product price, and can also increase their competitiveness.

\section{References}

1. Alıyev İ. H. Aqrar sahənin inkişafının təkmilləşdirilməsi və regionlarda islahatların keyfiyyətcə səmərəli aparılması [Improving the development of the agrarian sector and conducting reforms in the regions effectively]. Baku 2004 [in Azerbaijani].

2. 2008-2015-ci illərdə Azərbaycan Respublikasında əhalinin ərzaq məhsulları ilə etibarlı təminatına dair Dövlət Proqramı [State Program on Reliable Provision of Population with Food Products in the Republic of Azerbaijan for 2008-2015]. Retrieved from http:// www.e-qanun.az/framework/15320 [in Azerbaijani].

3. Azərbaycan Respublikası regionlarının 2009-2013-cü illərdə sosial-iqtisadi inkişafı Dövlət Proqramı [State Program of Socio-Economic Development of the regions of the Republic of Azerbaijan in 2009-2013]. Retrieved from http://www.e-qanun.az/framework/16721 [in Azerbaijani].

4. Azərbaycanın statistik göstəriciləri. Azərbaycan Dövlət Statistika Komitəsi Statistical [Statistical Indicators of Azerbaijan. State Statistical Committee of Azerbaijan]. Retrieved from https://www.stat.gov.az [in Azerbaijani].

5. Kenikstul V. I., Eremeyev V. I. (2010). Upravleniye selskim khozyaystvom v sovremennykh usloviyakh [Management of agriculture in the present-day context]. Kaluga: «Poligraph-Inform» Ltd. [in Russian]. 
6. Quliyev E. A. (2013). Ekonomicheskaya effektivnost intensifikatsii selskogokhozyaystvennogo proizvodstva [The economic efficiency of intensified agricultural production]. Aktualnyye problemy innovatsionnogo razvitiya agropromyshlennogo kompleksa Vital problems of the innovation-driven development in the agro-inducstrial complex. Makhachkala, s. 150 [in Russian].

7. Konakov M. A., Konakov A. P. (2004). Organizatsiya i ekonomicheskiye osnovy fermerskikh khozyaystv [Organization and economic grounds offarms]. Moscow: Akademiya [in Russian].

8. Sovetov I. (2003). Effektivno ispolzovat zemelnyye resursy [Using effectively land resources]. Ekonomika selskogo khozyaystva Rossii-Economics of agriculture in Russia, 4, 37-39 [in Russian].

9. Smagin B. I., Akindinov V. V. (2007). Effektivnost ispolzovaniya resursnogo potentsiala $v$ agrarnom proizvodstve [The effectiveness of exploitation of the resource capacities in the agrarian production]. Michurinsk: Michurinsk State Agrarian University [in Russian].

10. Kulikov N. D. (2002). Resursnyy potentsial selskogo khozyaystva i effektivnost ego ispolzovaniya [The resource capacities of agriculture and the effectiveness of their exploitation]. Saransk: Mordovia State University [in Russian].

11. Balatskiy E. (2004). Innovatsionnyye strategii kompaniy na razvivayushchikhsya rynkakh [Innovation strategies of companies on the emerging markets]. Obshchestvo $i$ ekonomika - Society and Economy, 4, 100-115 [in Russian].

12. Azərbaycan Respublikasının Dövlət Statistika Komitəsi. Retrieved from www.stat.gov. az [in Azerbaijani].

Bibliographic description for quotiong:

Tamrazov T. H. (2019). Improving Food Supply throught Increasing Local Production in Azerbaijan. Scientific Bulletin of National Academy of Statistics, Accounting and Audit - Naukovyy visnyk Natsionalnoi academiyi stattystyky, obliku ta audytu, 1-2, 14-23 [in English]. 